\title{
Economic Impact of Illness with Health Insurance but without Income Insurance
}

Sven Nee/sen ${ }^{a}$

Supon Limwattananon ${ }^{b, c}$

Owen O'Donnel/a,d,e

Eddy van Doorslaera,d

a Erasmus University Rotterdam, the Netherlands;

${ }^{b}$ Ministry of Public Health, Thailand;

'Khon Kaen University, Thailand;

a Tinbergen Institute, the Netherlands;

e University of Macedonia, Greece. 
Tinbergen Institute is the graduate school and research institute in economics of Erasmus University Rotterdam, the University of Amsterdam and VU University Amsterdam.

More TI discussion papers can be downloaded at http://www.tinbergen.nl

Tinbergen Institute has two locations:

Tinbergen Institute Amsterdam

Gustav Mahlerplein 117

1082 MS Amsterdam

The Netherlands

Tel.: +31(0)205251600

Tinbergen Institute Rotterdam

Burg. Oudlaan 50

3062 PA Rotterdam

The Netherlands

Tel.: +31(0)10 4088900

Fax: $+31(0) 104089031$

Duisenberg school of finance is a collaboration of the Dutch financial sector and universities, with the ambition to support innovative research and offer top quality academic education in core areas of finance.

DSF research papers can be downloaded at: http://www.dsf.nl/

Duisenberg school of finance

Gustav Mahlerplein 117

1082 MS Amsterdam

The Netherlands

Tel.: +31(0)20 5258579 


\title{
Economic impact of illness with health insurance but without income insurance
}

\author{
Sven Neelsen ${ }^{a^{*}}$, Supon Limwattananon ${ }^{\mathrm{b}, \mathrm{c}}$, \\ Owen O’Donnell ${ }^{\mathrm{d}, \mathrm{e}, \mathrm{f}}$, Eddy van Doorslaer ${ }^{\mathrm{a}, \mathrm{d}, \mathrm{e}}$
}

April 2015

\begin{abstract}
We examine economic vulnerability to illness when, as for informal sector workers in Thailand, there is universal coverage for health care but earnings losses are uninsured. Even with comprehensive health care entitlement, severe illness that strikes an initially healthy worker is found to raise out-of-pocket medical expenses by around two thirds and increase the probability that medical spending absorbs more than a tenth of the household budget by nine percentage points. Moreover, severe illness reduces the probability of remaining in employment by 18 points and precipitates a reduction in household labor income of almost one third. Despite the rise in medical expenses and fall in earnings, households are able to maintain expenditure on goods and services other than medical care by drawing on remittances and informal transfers, cutting back on saving, and by borrowing. In the short term, informal insurance fills gaps left uncovered by formal insurance but there is likely to be substantial exposure to economic risks associated with long-term illness.
\end{abstract}

JEL Classification: I13, J46, O12

Keywords: Health, medical expenditure, social insurance, universal coverage, Thailand

Acknowledgements: The research reported in this paper was financed by the EU FP7 project entitled Health Equity and Financial Protection in Asia (HEALTH-F2-2009-223166). Sven Neelsen received funding from the EU FP7 Marie Curie Intra European Fellowship HEALTHEVENT (PIEF-GA-2012-331815). Owen O’Donnell acknowledges additional support from the General Secretariat for Research and Technology (Greek Ministry of Education \& Religion).

${ }^{a}$ Institute of Health Policy and Management, Erasmus University Rotterdam, the Netherlands

${ }^{b}$ International Health Policy Program, Ministry of Public Health, Thailand

'Khon Kaen University, Thailand

${ }^{d}$ Erasmus School of Economics, Erasmus University Rotterdam

${ }^{e}$ Tinbergen Institute, the Netherlands

${ }^{f}$ Department of Balkan, Slavic and Oriental Studies, University of Macedonia, Greece

* Corresponding author: Sven Neelsen, Institute of Health Policy and Management, Erasmus University Rotterdam, P.O. Box 1738, 3000 DR Rotterdam, the Netherlands, E-mail address: neelsen@bmg.eur.nl 


\section{Introduction}

Illness poses two economic risks - medical expense and earnings loss. There is some evidence that the latter is the greater threat to living standards in developing countries (Gertler and Gruber 2002, Tanimura et al. 2014). Yet recent policy initiatives have concentrated on extending insurance against the former risk, and this is the focus of the push for universal health coverage led by the World Health Organization (2010). This is understandable. It is more feasible to provide publicly subsidized health care to families supported by the informal economy than it is to compensate informal sector workers for sickness-related earnings and production losses. It is also possible that medical care coverage indirectly provides income protection by making treatment affordable and so maintaining health and productivity. This is the basis of the economic argument for investing in health care in low- and middle-income countries (World Health Organization 2001, Jamison et al. 2013).

This paper examines the economic consequences of illness when there is universal coverage for health care but earnings losses are left uninsured. Thailand's landmark Universal Coverage Scheme provides a fairly comprehensive package of medical care benefits to the four fifths of Thais who are not insured through formal sector employment. It has been shown to have increased access to medical care and substantially reduced exposure to medical expenditure risk (Gruber et al. 2014, Limwattananon et al. 2015). But sickness- and disability-related earnings insurance in Thailand, as in other developing countries, remains restricted to formal sector employees who form less than a third of the workforce. We estimate the economic impact of illness on the informal sector workers who have health insurance but lack income insurance.

The absence of earnings insurance is an obvious reason for households remaining economically vulnerable to illness. Another is that health system resources may be overstretched by the attempt to offer broad coverage to a large fraction of the population that is economically dependent on the informal economy. Those entitled to cover may choose to pay out-of-pocket in order to avoid queues, access off-list medicines or uncovered treatments, and obtain care that is considered to be of higher quality. For these reasons, universal coverage is unlikely to deliver 100 percent financial protection even from medical expenses. We estimate the medical expenses incurred by a population with social health insurance and consider these alongside the income loss due to illness. Joint consideration of both risks is relevant in the context of calls to broaden the universal coverage 
agenda further to include social protection against indirect costs of accessing medical care and earnings losses associated with illness (Lönnroth et al. 2014).

Previous research on the economic impact of illness and injury in low- and middle-income countries (LMICs) has been restricted to settings with little or no formal insurance of either medical expenses or earnings (Townsend 1994, Gertler and Gruber 2002, Genoni 2012, Asfaw and Von Braun 2004, Wagstaff 2007, Islam and Maitra 2012, Mohanan 2013). In this context, the evidence shows ill-health provokes increased out-of-pocket (OOP) spending on medical care and reduced work activity with associated income loss (Gertler and Gruber 2002, Lindelow and Wagstaff 2005, Wagstaff 2007). Evidence on households' ability to smooth consumption in the short term over these economic impacts is mixed but tends to show that informal coping strategies such as dissaving, borrowing and assets sales can provide partial insurance (Townsend 1994, Genoni 2012, Islam and Maitra 2012, Mohanan 2013) but, particularly for the most severe health shocks, not full insurance (Dercon and Krishnan 2000, Gertler and Gruber 2002, Asfaw and Von Braun 2004). This research suggests that there are potential welfare gains from social insurance but that the latter is likely to partially crowd out informal insurance. However, given the lack of both health care and earnings insurance in the contexts studied, it has not always been clear which of the two would potentially generate the greater welfare gain. Further, the case for social insurance is based on the presumption that it will be effective in eliminating the risk that exists in its absence. Yet indirect costs on the demand side, as well as insufficiently resourced and inefficient public health care may result in a considerable gap between nominal entitlement and effective coverage.

We provide evidence on the extent to which illness continues to generate economic risk through OOP payments, as well as earnings losses, after universal health care coverage is put in place. In addition, we assess the extent to which households are able to cope with the residual risk, at least in the short term, by drawing on informal insurance mechanisms to maintain levels of expenditure on goods and services other than medical.

We use panel data to identify informal sector workers who are struck by the onset of a new health problem and discriminate between varying degrees of severity by the extent of any simultaneous change in reported health. A new health condition is estimated to reduce the probability of continuing in employment by almost 4 percentage points and by 18 points for those struck by the most severe conditions that provoke the greatest fall in reported health. Hours worked by the sick person are estimated to be reduced by 13 percent on average, rising to 46 percent for those with the 
greatest severity. Household labor income falls by an insignificant 6 percent on average and is reduced by a significant 27 percent for those with the most severe health shocks. This substantial fall in earnings is partially offset by a rise in non-labor income - mainly remittances and informal transfers - with the result that there is no significant impact on total household income, although the point estimate is an 8 percent reduction.

Conditional on the initial level of OOP health payments, as well as covariates, households in which an informal sector worker is struck by a new health condition are induced to raise their medical spending by 42 percent, while the most severe health shock increases OOP payments by half. These large relative effects are not necessarily burdensome if universal coverage has succeeded in keeping absolute levels of medical expenses low. To some extent, this is the case. But illness continues to result in major medical expenditure risks for some households. On average, the probability that spending on medical care absorbs at least ten percent of the household budget is raised by two percentage points and this effect rises to nine points for those struck by the most severe conditions.

Besides informal transfers and remittances, households cope with illness-induced earnings losses and medical expenses by cutting back on saving and by borrowing. On average, the onset of a health problem is associated with an insignificant 11 percent reduction in the amount saved, which rises to almost 100 percent for those experiencing the most severe illness. Borrowing is raised by one quarter on average and by 92 percent when severity is greatest. By exercising these coping strategies non-medical expenditure is held constant despite the substantial rise in spending on medical care and the fall in earnings.

The baseline estimates are obtained by comparing outcomes for observations struck by illness with those remaining healthy after conditioning on the lagged value of the outcome and covariates. They are generally robust to estimation in first differences instead, as well as to application of a doubly robust estimator that combines matching through inverse probability weights with regression.

Our findings reveal substantial economic impacts of illness through income loss and medical expenses. But, at least in the short run, informal insurance arrangements seem sufficient to fill many of the gaps in coverage that exist when universal health insurance is not accompanied by sicknessrelated earnings insurance. An important caveat is that the analysis is restricted to the impact in the period that illness strikes. If a health condition is chronic, which is increasingly the case in middleincome countries such as Thailand, then savings, remittances and borrowing will be insufficient to preserve living standards in the long run. In that case, there are likely to be substantial welfare gains 
from further extension to social insurance to protect against the risk of illness that permanently reduces earnings and raises medical expenses (Kowalski 2015).

The paper is organized as follows. Section 2 outlines formal social protection against financial risks associated with illness in Thailand and describes the data. The estimation method is presented in section 3. Results are presented in Section 4, and the final section concludes.

\section{Context and data}

\section{Social protection in Thailand}

Social protection in Thailand varies by employment sector. Public servants (10\% of the workforce) and their dependents enjoy comprehensive health care coverage, can take sick leave on full pay for temporary illnesses and receive accumulated pension benefits in case of retirement for medical reasons (International Labour Organization 2013). Private sector salaried employees must be enrolled in a social security scheme that gives entitlement to comprehensive health care benefits as well as paid sick leave and medical retirement benefits of up to $50 \%$ of pre-illness earnings (International Labour Organization 2013, Social Security Administration 2013). ${ }^{1}$ Coverage through this scheme is common only in medium and large sized enterprises ( $>50$ employees). ${ }^{2}$ In combination with the persistently high rate of informality, this results in only one third of the workforce holding health insurance and sickness-related earnings insurance through an employmentbased scheme. The remainder has health care coverage through the tax-financed Universal Coverage Scheme (UCS), which has been in place since 2001, but does not have any publicly subsidized coverage for illness-related income loss. ${ }^{3}$

The UCS provides fairly comprehensive coverage for ambulatory and hospital care, and delivers medicines from a restricted (mostly to generics) list. There is no cost-sharing after the removal of a flat fee of 30 Baht $(\sim 0.75)$ in 2006. Per capita funding is much less generous than the coverage provided to civil servants but the scheme has been found to have strongly increased health care access with consequent gains in health (Gruber et al. 2014) and to have substantially reduced OOP health payments (Limwattananon et al. 2015). Nonetheless, possibly due to long waiting times, limited facility opening hours or perceived quality deficiencies, over $40 \%$ of the scheme's intended

\footnotetext{
${ }^{1}$ Employers and the self-employed can voluntarily enroll in this scheme.

2 Less than two-fifths of employees of small enterprises (10-50 employees) and one-tenth of those engaged in micro enterprises ( $<10$ employees) reported enrollment in the social security scheme in 2007 (see Appendix Table A1).

${ }^{3}$ Since 2010, which is after our estimation period, this group receives a small (500 Baht $\left.\sim \$ 12.5\right)$ monthly pension if permanently disabled.
} 
beneficiaries report forgoing their entitlement and purchasing ambulatory care out-of-pocket. ${ }^{4}$ By contrast, $90 \%$ of beneficiaries use their coverage when accessing more expensive inpatient care.

\section{Sample}

Our data come from the nationally representative Thai Socio-Economic Survey (SES). In the 2005 round, 6,000 households (21,450 individuals) were randomly selected from the cross-section to form a panel that was re-interviewed in both 2006 and $2007 .^{5}$

Table 1: Percentage of informal workers covered by various social insurance schemes, 2007

\begin{tabular}{llc}
\hline \hline \multicolumn{1}{c}{ Scheme } & \multicolumn{1}{c}{ Benefits } & $\%$ \\
\hline Uninsured & None & 4.47 \\
Universal Coverage Scheme & Health care & 85.69 \\
Social Security Scheme & $\begin{array}{l}\text { Health care, sick pay \& medical retirement at up to 50\% } \\
\text { earnings }\end{array}$ & 3.28 \\
Civil Servants Medical & $\begin{array}{l}\text { Health care (+ for dependents), sick pay at 100\% } \\
\text { earnings, medical retirement with accumulated pension } \\
\text { Benefit Scheme }\end{array}$ & 5.60 \\
Other & Private health insurance & 0.96 \\
Total & & 100 \\
\hline
\end{tabular}

Note: Informal workers $=$ employers, the self-employed, unpaid family workers and employees of microenterprise ( $<10$ employees). Together, these groups constitute over $75 \%$ of the Thai workforce.

We are interested in economic vulnerability to illness in the part of the workforce that is engaged in the informal economy, has medical benefits coverage through the universal scheme and is without earnings insurance. Unfortunately, the survey provides information on health/disability insurance coverage only in the last wave of the panel. Since social protection through either of the employment-based schemes that provide both health care and income replacement benefits is low among employers, the self-employed, family workers and micro-enterprise employees, we make these categories of employment the first selection criterion for inclusion in our main analytic sample, and, for brevity, refer to these individuals as informal workers. ${ }^{6}$ Table 1 shows the coverage of these individuals identified from the 2007 wave. Ninety percent have health insurance but no income insurance through the universal scheme or have no cover whatsoever. Inclusion in the sample of the remaining ten percent that is covered through the employment-based schemes, which provide more generous medical benefits as well as sickness pay and disability-related retirement benefits, is

${ }^{4}$ Authors' analysis of data from the 2009 and 2011 rounds of the Thai Health and Welfare Survey.

${ }^{5}$ In 2006 (2007) 4.5\% (4\%) of households were lost to attrition. Those leaving the panel tend to be younger and of higher socioeconomic status. As such, they are less likely to be in the group of interest - informal sector workers.

${ }^{6}$ Employers and the self-employed are not necessarily engaged in the informal sector. They may well have registered their businesses. But, as is evident from Table A1, very few of them choose to enroll in the social security scheme. 
expected to result in a downward bias in our estimates of the extent to which illness impacts on household finances among those engaged in the informal economy.

\section{Illness measure}

All household members age 14 and over are asked if they experienced a health problem over the last 12 months. They are also asked to assess their health compared to that of others their age by choosing between the descriptions of very good, good, fair, or poor. Self-reported measures have been shown to capture substantial variation in health, predicting functional limitations and even mortality conditional on batteries of objective health indicators (Idler and Kasl 1995, Idler and Benyamini 1997). They have been used extensively to estimate the impact of ill-health on labor market outcomes in high-income countries (for a review, see O’Donnell et al (2015)) and they have frequently been used to test whether households can smooth consumption over claimed health shocks in LMICs (Townsend 1994, Gertler and Gruber 2002, Asfaw and Von Braun 2004, Wagstaff 2007, Genoni 2012, Islam and Maitra 2012). Potential measurement error is a recurrent concern. If this is classical, then it will result in underestimation of any impact of ill-health, which is more of a problem for a test of consumption smoothing than it is for estimated effects on medical expenses and income that can be presumed to be lower bounds. Systematic differences in the reporting of health that are correlated with these outcomes would be a greater problem. This has been a major concern in the literature on the impact of health on employment in high-income countries where disability insurance may create an incentive to withdraw from the labor force and report poor health (Bound 1991). In the current context, in which the population of interest has no disability insurance, this is not an issue.

Like Asfaw and Von Braun (2004), we deal with any time invariant differences in the reporting of health by restricting the sample to individuals who initially report themselves to be healthy and utilize only information on health changes from that level. Specifically, we restrict attention to informal workers, as defined above, who report in the first wave not to have experienced a health problem in the last 12 months and who initially rate their health as very good or good. Following these individuals to the next wave, we distinguish those who report a health problem in that 12 month period (treatment group) from those who again report no experience of a health problem (control group). The former group is then dropped from the sample and we follow the latter group to identify those who experience a health problem by the final wave. This gives a pooled sample of 
6,469 observations who are initially healthy informal workers and who are observed in (at least) two consecutive waves. ${ }^{7}$

To identify health problems of different degrees of severity, we distinguish between a health problem onset that coincides with: (1) a drop in self-assessed health between waves from very good/good to poor, (2) a drop from very good/good to fair, and, (3) self-assessed health remaining as very $\operatorname{good} / \operatorname{good}^{8}$

Table 2: Treatment and control observations in individual and household level samples

\begin{tabular}{|c|c|c|c|c|}
\hline \multirow[b]{3}{*}{ Treated } & \multicolumn{2}{|c|}{ Individuals } & \multicolumn{2}{|c|}{ Households } \\
\hline & Observations & $\%$ & Observations & $\%$ \\
\hline & & & & \\
\hline Onset of health problem & 879 & 13.6 & 773 & 18.5 \\
\hline \& drop to poor health & 77 & 1.2 & 72 & 1.7 \\
\hline \& drop to fair health & 411 & 6.4 & 373 & 8.9 \\
\hline \& remain in very good/good health & 391 & 6.0 & 349 & 8.4 \\
\hline Controls & & & & \\
\hline No onset of health problem & 5,590 & 86.4 & 3,402 & 81.5 \\
\hline Total & 6,469 & 100 & 4,175 & 100 \\
\hline
\end{tabular}

Notes: The individual level sample consists of individuals who work in the informal sector, report no health problem in the last 12 months and very good or good health in one wave and who are observed in the subsequent wave. The household sample consists of households with at least one individual qualifying for the individual sample in one wave who is observed in the subsequent wave. The number of households in which there is a person who experiences the onset of a health problem (773) is less than the sum of the number of households with a health problem onset combined with each of the three potential changes in self-assessed health $(72+373+349)$ because there can be multiple persons within a household who experience a health problem onset.

Across the three waves of the panel, 13.6\% of observations experience the onset of a health problem between consecutive waves (Table 2). The onset coincides with a drop in self-assessed from very good/good to poor health for $1.2 \%$ of the pooled sample, whereas $6.4 \%$ experience a drop to fair health and around the same fraction continues to report very good/good health despite the reported occurrence of a health problem. The rarity of a health problem onset combined with a drop to poor health suggests that this identifies the most severe illnesses.

This interpretation is supported by the fact that the incidence rates of more severe conditions, such as neurodegenerative disorders, cardiovascular disease, and gastrointestinal, hepatic and renal

\footnotetext{
${ }^{7}$ Of the initially healthy informal workers, 6.8\% (5.6\%) are lost to follow-up 2005-06 (2006-07). Attrition in this sample is correlated with younger age, better education, a higher propensity to work in white collar occupations and urban residence.

8 Individuals who report no health problem in the last 12 months but whose reports of self-assessed health in subsequent waves correspond to a drop from very good/good to fair or poor are included in the control group. Excluding them has little effect on the results.
} 
diseases $^{9}$, are highest among those who fall into this group (Table 3). ${ }^{10}$ Further, incidence rates of conditions that are generally less severe or life-threatening, such as musculoskeletal problems, ear, nose and throat problems and skin disorders, are highest in the group that continues to report very good/good health.

Table 3: Incidence of particular health conditions in the informal worker sample that experiences the onset of a health problem $(\%)$

\begin{tabular}{|c|c|c|c|c|}
\hline & \multirow{2}{*}{$\begin{array}{l}\text { All with } \\
\text { onset of } \\
\text { health } \\
\text { problem }\end{array}$} & \multicolumn{3}{|c|}{ Onset of health problem +} \\
\hline & & $\begin{array}{l}\text { drop to poor } \\
\text { health }\end{array}$ & $\begin{array}{l}\text { drop to fair } \\
\text { health }\end{array}$ & $\begin{array}{l}\text { remaining in } \\
\text { very good or } \\
\text { good health }\end{array}$ \\
\hline Cancers & 0.57 & 1.3 & 0.49 & 0.51 \\
\hline Neurodegenerative disorders & 2.73 & $10.34^{* *}$ & 2.43 & 1.53 \\
\hline Diabetes & 4.44 & 3.9 & 5.11 & 3.84 \\
\hline Cardiovascular diseases & 4.99 & $9.09 *$ & $6.33^{* * *}$ & 2.56 \\
\hline Migraine/Chronic headaches & 5.69 & 3.9 & $7.30^{*}$ & 4.35 \\
\hline Eye, ear, nose \& throat problems & 8.65 & $3.90 * *$ & 8.76 & 9.46 \\
\hline Skin disorders, allergies and immune disorders & 8.76 & $3.90 * * *$ & $7.30^{*}$ & 11.25 \\
\hline Gastrointestinal, hepatic, renal disease & 13.31 & 20.78 & 12.41 & 12.79 \\
\hline Musculoskeletal problems & 30.03 & $22.08^{*}$ & 30.66 & 31.46 \\
\hline High/Low blood pressure & 30.48 & 20.78 & 21.41 & 19.44 \\
\hline Other & 10.58 & 16.88 & 9.49 & 10.49 \\
\hline Number of observations & 879 & 77 & 411 & 391 \\
\hline
\end{tabular}

Notes: Sample is restricted to individuals in the treatment group i.e. informal workers in initially without a health problem in last 12 months and reporting health as very good/good who develop a health problem. Figures show the percentage of the individuals who report each condition. Up to two (most severe) conditions can be reported. ***, ** and $*$ indicate that the incidence rate for those reporting a drop to poor (fair) health is significantly different from the incidence rate for those remaining in very good/good health at the 1\%,5\% and 10\% level of significance respectively.

Consistent with known sociodemographic differences in health, individuals who experience a health problem differ in observable characteristics from those who do not. Before the onset of illness, the treatment group is older, more likely to be female and of lower education than those who remain without any health problem (Table 4, left-hand panel). Those struck by illness initially work fewer hours. We adjust for these differences in baseline characteristics in estimating the impact of illhealth.

\footnotetext{
9 The p-value for the test of equality of the incidence of gastrointestinal, hepatic, and renal diseases between the group without health problem onset and the group with a drop to poor health is 0.106 .

${ }^{10}$ Each individual who reports any health problem in the last 12 months is asked about the nature of the problem. Answers are coded into one of eleven disease categories. Up to two of the most severe conditions from which the respondent suffers can be reported.
} 
Estimation of the impact of health changes on household-level outcomes is done using a sample of households that include at least one informal worker who initially reports no health problem and very good/good health. Within this sample, we distinguish households in which there is an informal worker who experiences a health problem onset from those in which this does not occur. ${ }^{11}$ Illness strikes in $773(18.5 \%)$ of the 4175 households included in the sample that is pooled across the three waves (Table 2). The relative incidence rates of a health problem combined with different changes in selfassessed health reflect those observed at the individual level.

Table 4: Baseline (2005) means of outcomes and covariates for treatment and control groups

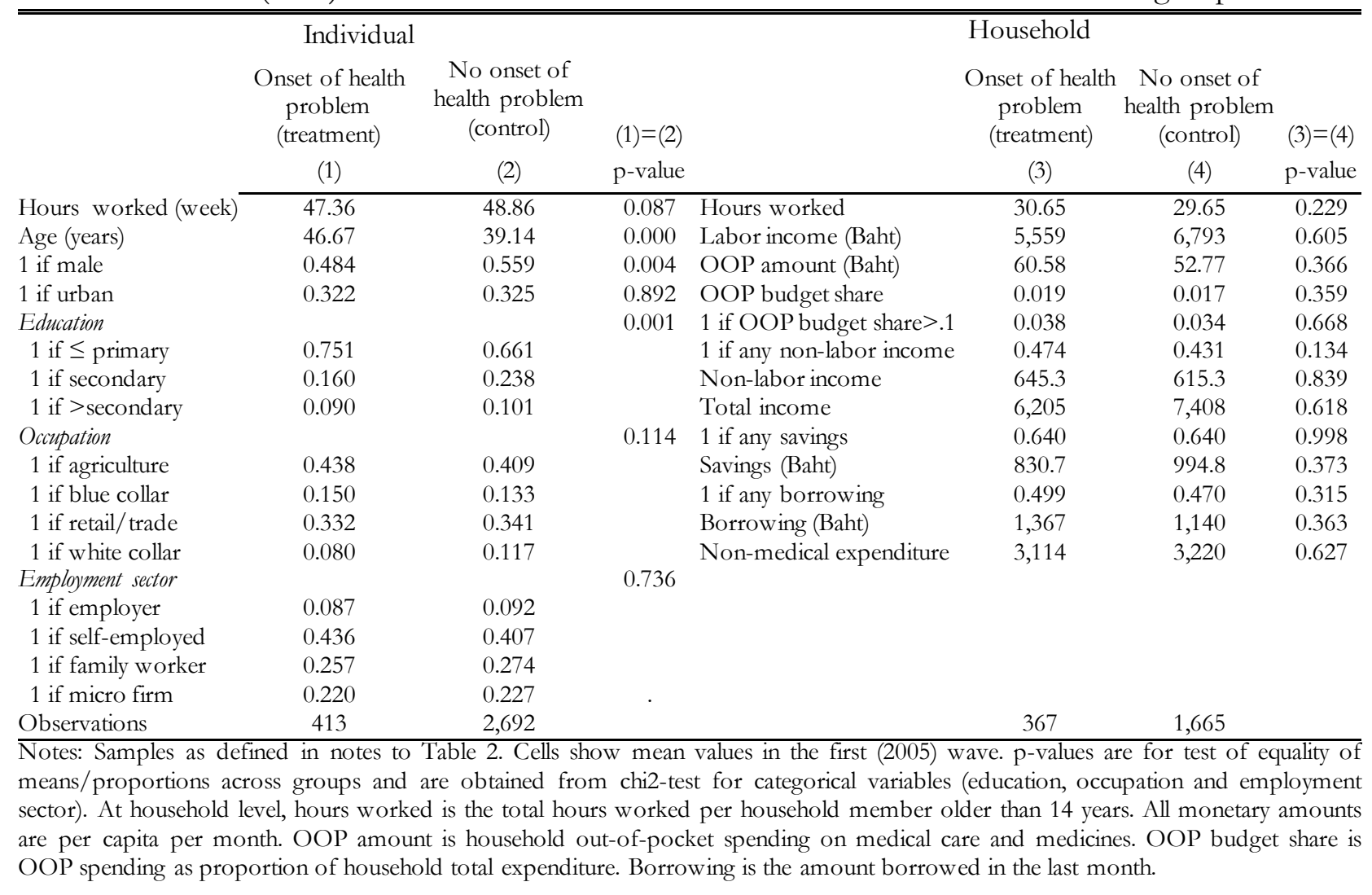

\section{Outcome variables}

We are interested in the economic impact of illness through earnings loss and medical expenses, and in the extent to which households can cushion the impact through informal coping mechanisms. We estimate the effect on individual employment and hours of work. The impact on individual earnings cannot be estimated because household labor income from agriculture and family business, two

\footnotetext{
11 If there is more than one informal worker in the household who is initially healthy, then the household can experience more than one health event. This rarely happens in the sample.
} 
important informal sector activities, is not disaggregated to the individual level. ${ }^{12} \mathrm{We}$ estimate the impact on household labor income, as well as on total hours worked by the household per person aged over 14 years. ${ }^{13}$ These effects will consist both of any direct effect on the activity of the person struck by illness and any spillover effects on other household members. The latter may be positive, in the case that there is substitution for lost earnings of the sick person (Sparrow et al. 2014), or negative, if others reduce work activity in order to provide care. There is no significant difference in baseline mean hours worked and in labor income across households distinguished by whether they contain an informal worker who later experiences a health problem (Table 4, right-hand panel). ${ }^{14}$

The survey asks the household to report average monthly OOP payments for health care and medicines over the last 12 months for all members older than 14 years. Unfortunately, payments made for the individual's own treatment are not adequately distinguished from payments made for the treatment of others. We therefore estimate the impact on household OOP payments. ${ }^{15}$ There is no significant difference between the treated and control households at baseline in the mean level of OOP payments and the mean share of total expenditure spent on medical care and medicines (Table 4, right-hand panel). Neither is there any significant difference in the proportion of households spending more than ten percent of total expenditure on medical care, which is sometimes taken as a threshold to define catastrophic health payments (Wagstaff and van Doorslaer 2003).

To examine the extent to which households exercise coping strategies to mitigate any impact of illness on earnings and/or medical expenses, we estimate effects on household non-labor income, saving and borrowing. Non-labor income includes transfers from both government and friends and relatives. Given our sample is engaged in the informal sector, the government transfers constitute less than $5 \%$ of non-labor incomes. ${ }^{16} \mathrm{We}$ also estimate the effect through both labor and non-labor sources on total household income. There is no significant difference between treatment and control

\footnotetext{
12 In our sample of individuals, $42 \%$ report agriculture as their main occupation and $27 \%$ are family workers. Agricultural income - the value of agricultural production (self-consumed and sold) minus expenses - is available only at the household level. There is an attempt to measure income/profits from non-agricultural business - sales value plus own consumption minus expenses - at the individual level. But of the family workers who engage in non-agricultural activities, $92 \%$ report no business income.

${ }^{13}$ Household labor income is the sum across household members of monetary and in-kind incomes from employment and profits from non-agricultural business (sales value plus own consumption minus expenses), plus the value of household agricultural production net of expenses.

14 See Appendix Table A2 for household level means of socio-demographic covariates.

15 We do find statistically significant, positive impacts of illness on OOP payments measured (inadequately) at the individual level. Results can be obtained from the corresponding author upon request.

16 Specifically, non-labor income is the aggregate of cash and in-kind transfers from other households, government transfers, pensions, severance payments, interest on money lent, capital income, lottery winnings and inheritances.
} 
households at baseline in the mean of either non-labor income or total income per capita, although the sample mean of the latter is markedly lower for the treated households. Savings are measured by the average monthly per capita amount saved over the past year. Each household reports the amount of money borrowed formally (from commercial banks, village funds) and informally (from family, friends and loan sharks) during the past year. ${ }^{17}$ There is no significant difference in the mean level of saving and of borrowing at baseline between treatment and control households, although the former are significantly more likely to have borrowed anything at all (Table 4, right-hand panel).

In addition to the effect on total household income, we assess the overall impact on household welfare by estimating the effect on per capita expenditure on goods and services other than medical care. This is the sum of expenditure reported for nine categories - housing, food, education, transport, recreation, donations to charity, transfers to other households, clothing and personal care, and all other expenditure. This aggregate is about 7\% lower in the treated households at baseline.

Non-medical expenditure cannot be combined with the value of consumption from household agricultural production and from family business activity, which are included in the measure of household income but cannot be separated out. ${ }^{18}$ Hence, household consumption cannot be measured, ruling out a test of households' ability to smooth consumption over health shocks. But we are able to test whether a household can maintain its level of spending on other goods and services, including food and shelter, during periods in which illness may reduce earnings and raise medical expenses. Further, the estimated impact on household income will include any effect through reduced consumption from self-produced agricultural goods and from the produce of family businesses.

\section{Estimation}

The baseline differences in some outcomes and covariates documented in Table 4 indicate that illhealth does not strike randomly. We mitigate the risk of confounding the illness effect by conditioning on lagged values of the outcome $\left(Y_{i t-1}\right)$ and covariates $\left(\mathbf{X}_{i t-1}\right)$ in models that take the form,

\footnotetext{
${ }_{17}$ Monthly average savings and annual borrowing are reported on the individual level in the Thai SES. We aggregate to the household level. The annual borrowing amount is divided by 12 to allow easy comparison with the other amounts that are monthly.

18 Respondents are asked to include both consumed and sold agricultural goods when reporting the total value of agricultural production for the past year, but are not requested to distinguish between the two. Similarly, consumption from family business production is not separated from that sold.
} 


$$
Y_{i t}=\alpha+\theta Y_{i t-1}+\beta \Delta \text { Health }_{i t}+\mathbf{X}_{i t-1} \boldsymbol{\gamma}+\boldsymbol{\delta}_{r t}+\varepsilon_{i t}
$$

where $\Delta$ Health $_{i t}$ is an indicator equal to 1 if a health problem occurs between periods $t-1$ and $t$ and $\boldsymbol{\delta}_{r t}$ is a set of region-specific period effects. ${ }^{19}$ For employment and hours of work, the unit of analysis is the individual. ${ }^{20}$ For the other outcomes, the model is estimated at the household level and in that case $\Delta$ Health $_{i t}$ indicates whether there is an informal worker in the household who experiences the onset of a health problem between waves. ${ }^{21} \mathrm{We}$ also estimate models in which the single treatment indicator is replaced by three indicators of the onset of a health problem in combination with varying degrees of change in self-assessed health, as described above.

The covariates included in the individual level models are those listed in the left-hand panel of Table 4. By restricting the sample to informal workers who are initially free of a health problem and report their health as very good/good, we perfectly match treatment and control observations on these indicators of good health. When household level outcomes are modelled, the sample is restricted to households including initially healthy informal workers and covariates are those listed in Appendix Table A2, which includes indicators of whether there is a formal sector worker, or a non-worker in the household who experiences the onset of a health problem allowing for the possibility that illness is correlated within the household. ${ }^{22}$

All continuous outcomes are estimated in logs. ${ }^{23}$ Estimation is by ordinary least squares with standard errors that allow for clustering at the individual (household) level.

$\beta$ corresponds to the causal effect of illness under the assumption that, conditional on the lagged value of the outcome and the covariates, the value the outcome would have taken in the absence of illness is not correlated with illness onset (Angrist and Pischke 2008, Imbens and Wooldridge 2009). For example, given an amount of household spending on medical care prior to the onset of illness experienced by an informal worker, the amount of spending that would have been incurred if there were no illness onset would not differ between households that actually do experience illness (of an informal worker) and those that do not. Initial levels of spending and the (counterfactual) changes in

${ }^{19}$ Four indicators are included to allow for trends that differ across the five broad geographic regions.

${ }^{20}$ Since the sample is restricted to informal sectors workers, the lagged dependent variable is obviously omitted in the model of employment.

${ }^{21}$ Hours of work are estimated at both the individual and household levels.

22 Demographics are controlled for in the individual level analysis by ten age group $\times$ gender indicators and in the household level analysis by the share of household members in 14 age group $\times$ gender categories.

23 Zero and negative values are replaced by the $\log$ of the minimum positive value, minus 0.01 . All results are robust to replacement by 0 rather than this value. 
spending in the absence of illness onset are allowed to differ between treatment and control households. An alternative identification strategy would assume equal counterfactual changes between treatment and controls and estimate in first differences to remove the (assumed) time invariant level differences. We find this approach somewhat less plausible because it does not allow for the possibility that the trajectory of (counterfactual) medical spending (income, etc.) differs. For example, one would expect the probability that an informal worker contracts a health problem to be higher in households in which there is greater (unobserved) ill-health among relatives or greater exposure to health hazards. The dynamics of medical spending in such households are likely to differ from those in healthier households in which it is also less likely that an initially healthy informal worker develops a health problem. The lagged value of medical spending may proxy for the unobserved health environment. Conditional on that lagged value, current spending may not be expected to differ between treatment and control households if the informal worker were not to suffer illness. Of course, it is impossible to know if either identification strategy is valid and, following the advice of (Angrist and Pischke 2008), we check whether the estimates obtained differ markedly from those given by estimation in first differences.

We also examine robustness of the lagged dependent variable model estimates to the application of inverse probability weights in the regressions to effectively match on baseline values of the outcomes and covariates (Robins and Rotnitzky 1995). ${ }^{24}$ While this estimator has the attractive property of being doubly robust ${ }^{25}$, we present the estimates without weighting as the baseline results because it is not clear how to construct the weights in the case in which there are multiple treatments defined by different degrees of change in self-assessed health. This robustness check is therefore limited to the estimated average effects of the onset of any health problem.

\footnotetext{
${ }^{24}$ A weight equal to $\hat{p}\left(Y_{i t-1}, \mathbf{X}_{t-1}\right) / 1-\hat{p}\left(Y_{i t-1}, \mathbf{X}_{t-1}\right)$ is given to each control observation, where $\hat{p}\left(Y_{i t-1}, \mathbf{X}_{i t-1}\right)$ is the logit estimated propensity score of experiencing the onset of a health problem. Greater weight is therefore given to control observations that are more similar with respect to baseline characteristics to individuals (households) who experience the onset of illness. Treated observations are given a weight of 1.

25 A consistent estimator is obtained if either the propensity score model or the regression model, but not necessarily both, is correctly specified.
} 


\section{Results}

\section{Effects on work and earnings}

The onset of a health condition is estimated to reduce the probability that an informal worker remains in employment by just less than four percentage points and to reduce hours worked per week by 13 percent (Table 5, top row). ${ }^{26,27}$ Considering that all individuals were initially in employment, these are not particularly large effects. There is, however, substantial heterogeneity by the severity of illness. For those who report a decline from very good/good to poor health in conjunction with the onset of a health condition, we estimate that the probability of continued employment is reduced by 18 points and hours worked are decreased by 46 percent (Table $5,2^{\text {nd }}$ row). The estimated effects are substantially smaller for those who report a fall in health to fair and there is no statistically significant impact on those who continue to report very good/good health. All estimated effects differ significantly across the groups distinguished by the change in self-assessed health with one exception (Table 5, bottom panel). This dose-response relationship gives some face validity to the estimates.

At the household level, hours worked per working aged (14+) person are estimated to be reduced by $4.2 \%$ as a consequence of an informal worker falling ill and household labor income falls by a similar percentage, although only the former effect is significant. One cannot infer the impact on the work activity of other household members by comparing the relative effects on individual and household hours since the latter will be smaller even if others do not change their labor supply. If we estimate in levels, rather than logs, then we find a highly significant 1.6 hour reduction ( $\mathrm{p}$-value 0.004 ) on the individual level. The household level impact is smaller in magnitude (-0.34) and not significantly different from zero ( $\mathrm{p}$-value $=0.518$ ), suggesting that other household members do compensate, on average, for the lost work effort of the sick person. Again, the estimate effects of a health problem in combination with a drop to poor health are substantially larger. Household work hours are estimated to be reduced by $18 \%$ and labor income is estimated to decrease by $27 \%$. This more severe health event does appear to result in a very substantial loss of household earnings. The point estimates of the effects of a health problem in combination with a drop to fair health are smaller in magnitude and smaller again when there is no change in self-assessed health, and for these

\footnotetext{
26 All (semi-) elasticities quoted in the text are calculated using $\exp (\beta)-1$.

27 These estimates and all others presented in this sub-section are robust to defining treatment as a health problem experienced by a prime-age (20-59 years) informal worker. Therefore, it does not appear to be the case that the estimated effects are diluted by the inclusion of less active older individuals in the sample (Galiano and Hernández 2008).
} 
treatments no effect is significantly different from zero. While the effects do not differ significantly across the levels of treatment, the ordering of magnitudes is indicative of impacts on household labor supply and earnings increasing steeply with the severity of the health condition.

Estimates of the effects of any health problem on individual employment and work hours obtained from the inverse probability weight estimator and from a first difference model are very similar to those obtained from model (1) without the application of weights (see Appendix Table A4). ${ }^{28}$ Estimation in first differences gives significant effects even for a health problem that is not accompanied by any change in self-assessed health. The estimated effects on the household level outcomes in Table 5 are also robust to application of weights, and the magnitude and significance of these effects increase when estimated in first differences. Unlike the baseline estimates, the firstdifference estimate of the effect on household labor income appears to be driven by the impact on households with a health problem onset that does not coincide with a drop in self-assessed health. Otherwise, the dose-response relationship is maintained.

Table 5: Estimated effects of the onset of a health problem on labor supply and labor income

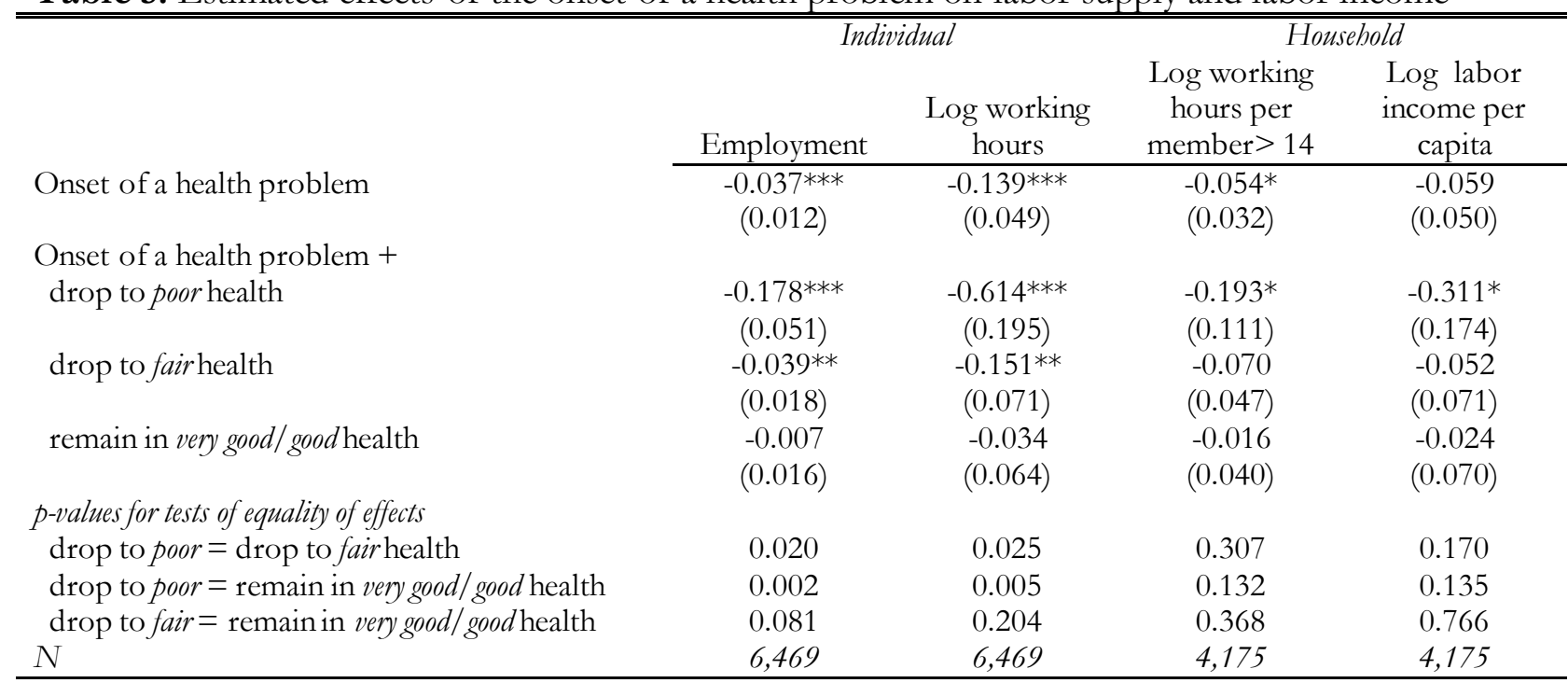

Notes OLS estimates of models akin to (1) with covariates as described in the text. Samples as defined in notes to Table 2. Standard errors clustered at individual/household level in parentheses. $* * *, * *, *$ indicate statistical significance at 1,5 and $10 \%$ levels.

28 Given that health shocks potentially impact labor market status, the work-related covariates i.e. occupation and employment sector, and the number of workers in the household, are excluded from the first differences model. Estimates from the lagged dependent variable model are robust to the exclusion of these covariates (at baseline) (see Appendix Table A4). 


\section{Effects on medical expenses}

We estimate that an informal worker suffering a health problem results, on average, in a $71 \%$ increase in household per capita OOP spending on medical care and medicines (Table 6, top row). While this would appear to be a very large increase, the initial mean level of medical spending by the treatment group is rather modest at $200 \mathrm{Baht}(\sim 5.00)$ per household per month. We estimate that the onset of illness raises the share of total household expenditure spent on medical care by 0.6 percentage points, or 38\% compared to the baseline mean of 1.6 percent. ${ }^{29}$ This substantial relative impact on the mean does not explicitly reveal increases in very large medical expenses that result from illness. Initially, 2.6 percent of households in the treatment group were spending more than $10 \%$ of their budgets on medical care. We estimate that illness of an informal worker raises the percentage incurring so-called catastrophic health payments by 2.1 points, a substantial increase.

Table 6: Estimated effects of the onset of a health problem on household out-of-pocket medical expenditure (OOP)

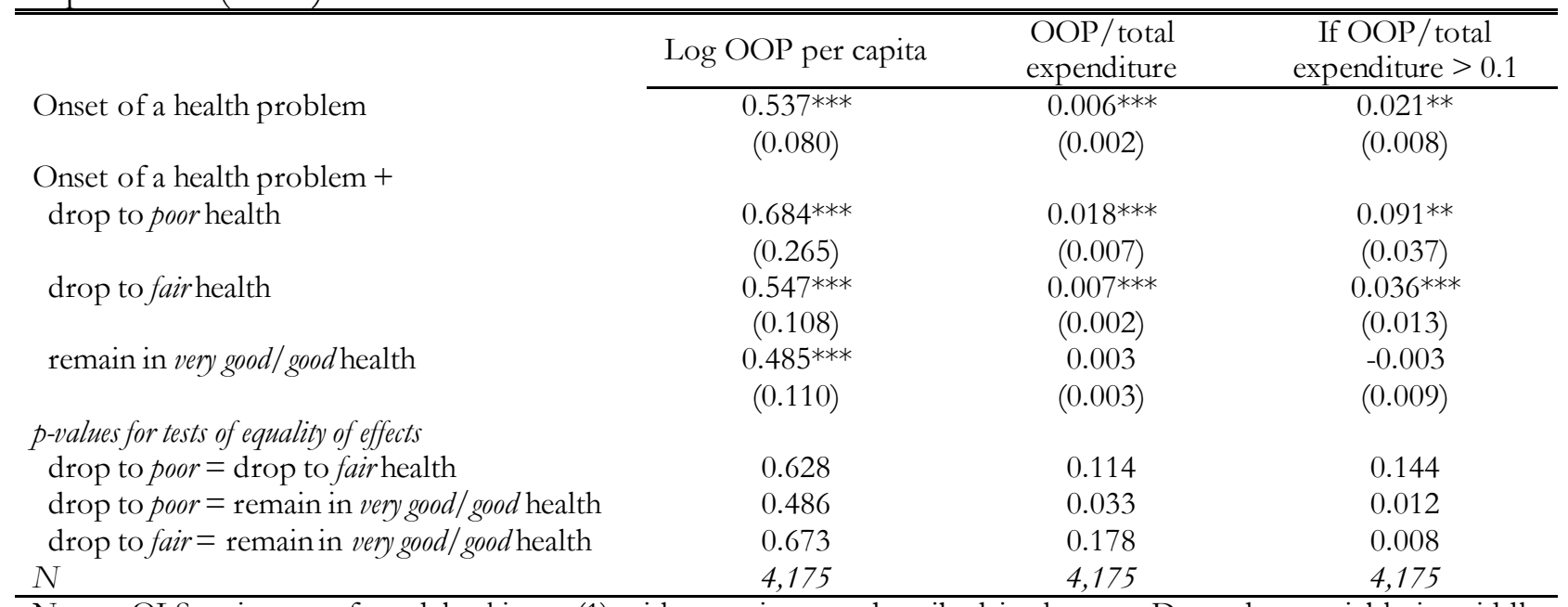

Notes: OLS estimates of models akin to (1) with covariates as described in the text. Dependent variable in middle column is the share of OOP medical spending in total household expenditure. Dependent variable in right-hand column is an indicator of whether this share exceeds one tenth. Samples as defined in notes to Table 2. Standard errors clustered at household level in parentheses. ${ }^{* * *}, * *$ indicate statistical significance at $1 \%$ and $5 \%$ levels.

The effects on medical spending increase with the severity of illness or injury as proxied by the degree of change in self-assessed health, although not always significantly so (Table 6, middle panel). The amount paid OOP is estimated to be raised by almost $100 \%$ by a health condition that coincides with a drop to poor health. The point estimate is smaller, but not significantly, when

${ }^{29}$ A 30 Baht $(\sim \$ 0.75)$ copay levied on non-poor UCS beneficiaries for each care episode was abolished in 2006. Neither separate analysis of 2005 (copay) and 2006 (no copay) sub-samples, nor interaction of the health problem onset indicator with a year indicator suggests that the copay removal had an impact on the relative or absolute OOP health expenditure effect of a health shock. Results are available on request. 
reported health drops to fair and when it remains at very good/good. The presumed most severe health event is estimated to raise the share of the household budget spent on medical care by 1.8 percentage points from a base of only 0.8 percent (see Appendix Table A3 for the latter). This is substantially, and in one case significantly, larger than the effect of less severe health changes on the medical budget share. Onset of a health problem together with a drop to poor health is estimated to raise the probability of the household spending more than $10 \%$ of its budget on health care by around 9 percentage points from a baseline of less than 1 percent (Table A3). Effects of the less severe health changes are markedly and significantly smaller.

It is interesting that before the onset of a health problem, means of the amount spent on medical care, its budget share and the prevalence of catastrophic payments were all lowest for the treatment group that subsequently experiences the onset of a health problem in combination with a drop to poor health (Table A3). This would suggest that this group experienced not only the most severe conditions but also the most acute illnesses and injuries most likely to prompt an abrupt downward revision the assessment of health.

Previous research has demonstrated that the extension of health coverage to the informal sector did greatly reduce OOP spending, particularly at the top of the distribution (Limwattananon et al. 2015) resulting in a substantial welfare gain from the reduction in exposure to medical expenditure risk. The current findings show that the risk of medical expenses associated particularly with the most severe and acute illnesses has by no means been eliminated.

The estimated effects presented in Table 6 are very robust to application of inverse probability weights and estimation in first differences (see Appendix Table A5).

\section{Coping with the economic impact of illness}

It appears that illness of an informal worker reduces work activity and earnings, and it increases medical expenses, with the effects of more severe illness being substantial. Can households deploy informal insurance mechanisms to cushion the short-term impact of these negative economic consequences? The point estimate of the impact on the probability of saving and on the (log) amount saved are both negative but neither is significant (Table 7). Being struck by illness is estimated to raise the probability of borrowing by 5.6 percentage points and to raise the amount borrowed by a third (Table 7). Onset of a health problem is estimated to raise the probability that the household has a non-labor source of income by 4.2 percentage points and to raise the amount 
received by 31 percent (Table 7). This income increase, which - as mentioned earlier - is likely to mainly take the form of remittances and transfers from relatives, would appear sufficient to offset the 6 percent decline in labor income (not significant) with the result that there is no significant impact on total household income (Table 8). On average, informal support appears to protect household income from the impact of sickness-related earnings losses, at least in the short term. ${ }^{30}$

Table 7: Estimated effects of the onset of a health problem on monthly savings, borrowing and non-labor income

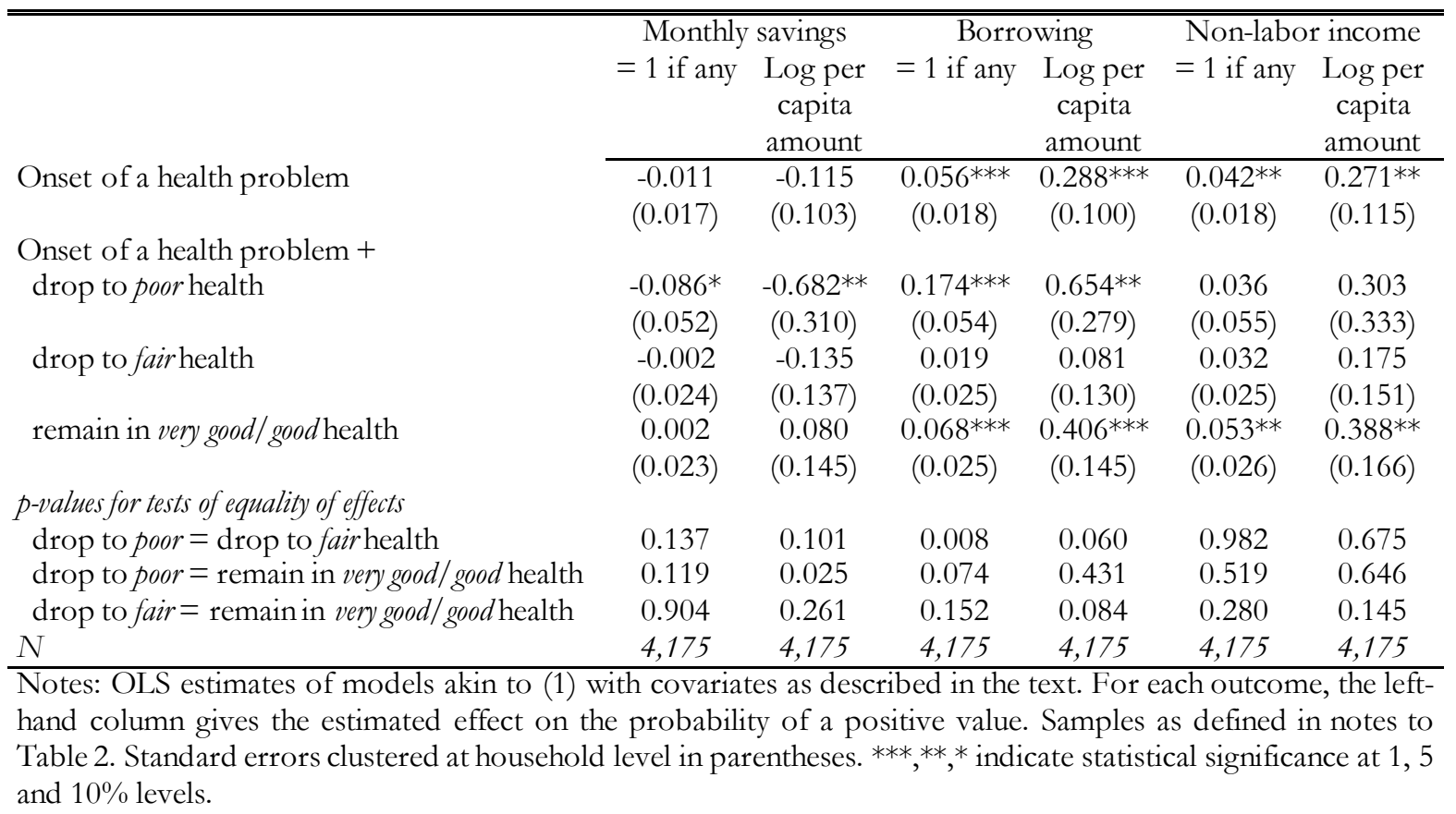

Deployment of these coping strategies is sufficient to hold mean expenditure on non-medical goods and services constant (Table 8) despite the $71 \%$ increase in mean spending on medical care, corresponding to a 0.6 percentage point increase in the share of the household budget absorbed by medical care and medicines. It bears emphasis that these are average effects. It does not necessarily follow that households that incur very high medical expenses as a consequence of illness or injury are able to maintain the same level of spending on other goods. In particular, the estimated 2.1 percent of households induced to spend more than $10 \%$ of their budgets on medical care may well have to sacrifice consumption, as well as reducing savings and resorting to borrowing.

\footnotetext{
30 A caveat, mentioned earlier, is that the treatment group does include some individuals who are covered by the formal sector social insurance schemes (Table 1). Earnings replacements transfers from these schemes will be included in nonlabor income. However, given the small fraction with such cover, this is unlikely to be a major explanation for the positive impact on non-labor income that is observed. Additional analysis (available on request) confirms that the income smoothing is mainly achieved through remittances/transfers from other households, and not from public transfers.
} 
The estimated effects of a health problem accompanied by a decline in self-assessed health to poor are generally larger in magnitude (Tables 7 and $8,2^{\text {nd }}$ row). This is not true for the impacts on nonlabor income. Although it is not significant, the negative point estimate of a 7.5 percent reduction in total income gives some indication that households struck by more severe illnesses are not able to fully replace the $27 \%$ loss of labor income with remittances and transfers. ${ }^{31}$ The monthly savings of these households are reduced by $49 \%$ and their borrowing is raised by $92 \%$ as a result of severe illness. $^{32}$ This heavy resort to debt, as well as the cut back on savings and possibly other coping mechanisms such as asset sales, appears just about sufficient to finance the $98 \%$ increase in mean spending on medical care, corresponding to a 1.8 percentage point increase in the budget share, without substantially reducing non-medical spending, although the insignificant point estimate indicates a $2.5 \%$ reduction in expenditure on other goods and services.

Table 8: Estimated effects of the onset of a health problem on household total income and non-health expenditure

\begin{tabular}{|c|c|c|}
\hline & $\begin{array}{l}\text { Log per capita total } \\
\text { income }\end{array}$ & $\begin{array}{l}\text { Log per capita non- } \\
\text { health expenditure }\end{array}$ \\
\hline Onset of a health problem & $\begin{array}{c}0.009 \\
(0.028)\end{array}$ & $\begin{array}{c}0.020 \\
(0.020)\end{array}$ \\
\hline $\begin{array}{l}\text { Onset of a health problem }+ \\
\text { drop to poor health }\end{array}$ & $\begin{array}{l}-0.078 \\
(0.083)\end{array}$ & $\begin{array}{l}-0.025 \\
(0.059)\end{array}$ \\
\hline drop to fair health & $\begin{array}{l}-0.003 \\
(0.039)\end{array}$ & $\begin{array}{l}-0.000 \\
(0.027)\end{array}$ \\
\hline remain in very good/good health & $\begin{array}{c}0.048 \\
(0.037)\end{array}$ & $\begin{array}{l}0.054 * * \\
(0.027)\end{array}$ \\
\hline $\begin{array}{l}\text { p-values for tests of equality of effects } \\
\text { drop to poor }=\text { drop to fair health } \\
\text { drop to poor }=\text { remain in very good } / \text { good health } \\
\text { drop to fair }=\text { remain in very good } / \text { good health } \\
N\end{array}$ & $\begin{array}{l}0.999 \\
0.484 \\
0.246 \\
4,175 \\
\end{array}$ & $\begin{array}{l}0.940 \\
0.788 \\
0.540 \\
4,175 \\
\end{array}$ \\
\hline
\end{tabular}

The signs of the estimated effects of a health problem combined with a drop in self-assessed health to fair on non-labor income, total income, monthly savings, borrowing and non-medical expenditure are all consistent with those of the effects of a drop to poor health, but the magnitudes are generally much smaller and no effect is significant. A health problem that is not accompanied by any change

\footnotetext{
31 The lack of significance of some effects for the group experiencing a drop to poor health may be attributable to a lack of power given that there are only 72 households in this group. This, in combination with the skewed nature of distributions of some of the outcomes, may also explain why few of the estimated effects differ significantly across the three sub-treatment groups.

32 The borrowing increase may partly be through uptake of social credit that offers a no-interest loan of up to 40,000 Baht ( 1,250 US\$) to the permanently disabled (Ministry of Labour. 2012).
} 
in self-assessed health is estimated to have significant positive effects on non-labor income and borrowing. Surprisingly, a health problem of this sort is estimated to raise household expenditure on other goods and services by $5.5 \%$. While we should perhaps not read too much into this result given that it is not robust to estimation in first differences (Appendix Table A7), a possible explanation is that there is increased need to spend on goods and services that accommodate the health condition (Jones and O'Donnell 1995). This may include costs of transport and personal care, two items that are included in the non-medical expenditure aggregate. Both the higher prevalence of musculoskeletal problems in this group (Table 2) and its larger baseline medical expenditures (Appendix Table A3) are consistent with higher levels of disability that is likely to have associated non-medical costs. The possibility that ill-health changes preferences, and not only constraints, has not been adequately addressed in almost all the literature that attempts to test consumption smoothing over health shocks (Galiano and Hernández 2008).

Apart from the estimate just mentioned, the effects presented in Tables 7 and 8 are generally similar to those obtained with application of propensity score weights and from estimation in first differences, although there are a few instances in which magnitude and significance falls (see Appendix Tables A6 and A7).

\section{Conclusion}

Our analysis reveals that substantial economic risks associated with illness remain even after universal health coverage is put in place. These risks do not only take the form of earnings losses that remain uninsured. There is also residual medical expenditure risk. This does not amount to failure of universal coverage in Thailand. The scheme is widely considered to be effective. It has been demonstrated to have raised access to medical care, reduced infant mortality and substantially reduced medical expenditure risk (Gruber et al. 2014, Limwattananon et al. 2015). Rather, the present study makes clear that any attempt at full population coverage on a tight budget - public health expenditure was $2.3-2.7 \%$ of GDP in Thailand during our estimation period - with minimal or no copayments is likely to result in gaps in effective coverage. The out-of-pocket spending of those entitled to care through the universal coverage scheme will include the 30 Baht $(\sim \$ 0.75)$ flat fee that was levied until 2006, purchases of medicines that are not on the essential drug list to which cover is restricted, fees for care in the private sector and at higher level public hospitals without referral, and expenditure on a few high cost treatments like renal dialysis and organ transplantation 
that were not covered during the study period. The omission of expensive treatments from the benefit package leaves household exposed to major risks. Such gaps may be partly responsible for the estimated 9 percentage point increase in the probability of spending more than a tenth of the household budget on health care as a result of a severe illness. The extension of coverage to these risks, as was done with dialysis in Thailand in 2008, would potentially generate substantial welfare gains. But the difficulty of achieving this on a modest budget has to be recognized.

Whether the deepening of coverage to eliminate the other types of OOP spending would be welfare improving depends on the balance between gains from reduced risk exposure and losses from moral hazard. Off-list purchases of medicines are partly for brand names that may be preferred to the generic equivalents on the restricted list. This choice is likely to bring little or no gains in health. In that case, the scales tilt in the direction of not deepening coverage. But some purchases could be of medicines that are not on the list because of their high cost despite being of major therapeutic value. If funding, which is heavily constrained by the predominantly informal nature of the economy, could be increased, then there would be a stronger case for including such medicines in the benefit package. ${ }^{33}$ Similar arguments must be weighed in considering whether payments for private care that are made in order to avoid waiting for treatment in public facilities give cause for concern.

The case for at least some insurance of sickness-related earnings losses is more straightforward. That does not make it any easier to identify feasible policies that could effectively reduce exposure to this risk. As long as a very large proportion of the workforce remains in the informal sector, it will be difficult to compensate for earnings losses. To an extent, our results suggest that the welfare loss from this impasse may not be as great as might be imagined. We find that households can call on informal insurance mechanisms that, on the whole, maintain their expenditure on other goods and services when illness, even serious illness, causes them to lose earnings and spend substantially more on medical care. ${ }^{34}$ While this is somewhat reassuring, three important caveats need to be emphasized in interpreting this finding and those from the consumption smoothing literature more generally.

First, we were not able to separately identify the impact on consumption from household, including agricultural, production. But this is included in the measure of household labor income and we estimate that severe illness reduces this by almost one third. A further reason why the impact of

33 The Thai Ministry of Public Health has set up a technology assessment agency whose job is to weigh the case for inclusion of therapies in the benefit package in the basis of cost-effectiveness analysis (Tantivess et al. 2009).

${ }^{34}$ This challenges a basic premise of the so-called catastrophic health payments measure, i.e. OOP payments in excess of some fraction of the household budget, that maintains that each dollar spent on medical care is at the expense of a dollar spent on other goods (Wagstaff and van Doorslaer 2003, Xu et al. 2003). 
illness on non-medical expenditure, and even consumption, may provide an upper bound estimate of the effect on welfare is because ill-health, particularly disability, may raise the need for expenditure on some non-medical items such as transport and personal care.

Second, we estimate the average effect of illness on expenditure. Even when we restrict attention to severe illness, there will be a distribution of effects around the mean. For some households, illness may cause a substantial reduction in resources available to spend on non-medical goods and services.

Third, as with the general consumption smoothing literature, we estimate short-term effects. These show the impact of illness within the last year on earnings, medical spending and non-medical expenditure within that year. The effects on the first two outcomes are large and that on the third is small because households marshal remittances, savings and borrowing to cover the costs incurred. If the illness is acute and in the following year the person returns to health and resumes work, then all is well and good. But in middle-income, and even low-income, countries, this is an increasingly less likely scenario. The rise of non-communicable diseases, along with HIV/AIDS, means that the risk faced is increasingly one of contracting a life-long illness that limits work capacity and raises medical care and medication needs permanently. Households cannot insure such risks through temporal reallocation of a given lifetime income. It is the size of their lifetime income and medical expenses that they need to insure. The literature needs to move beyond examination of the short-term economic impact of illness to understand better how chronic illness and disability impacts on earnings and medical expenses over a number of years. Of course, this requires longer panels than most of those currently available. 


\section{References}

Angrist, J.D. and J. Pischke (2008) Mostly Harmless Econometrics: An Empiricist's Companion. Princeton, NJ: Princeton University Press.

Asfaw, A. and J. Von Braun (2004) 'Is Consumption Insured Against Illness? Evidence on Vulnerability of Households to Health Shocks in Rural Ethiopia', Economic Development and Cultural Change 53(1): 115-129.

Bound, J. (1991) 'Self-Reported Versus Objective Measures of Health in Retirement Models', Journal of Human Resources 26(1): 106-138.

Dercon, S. and P. Krishnan (2000) 'In Sickness and in Health: Risk Sharing within Households in Rural Ethiopia', Journal of Political Economy 108(4): 688-727.

Galiano, A. and M.V. Hernández (2008) 'Health Shocks, Household Consumption, and Child Nutrition', Documentos de trabajo: Serie EC (Instituto Valenciano de Investigaciones Económicas) (14): 1.

Genoni, M.E. (2012) 'Health Shocks and Consumption Smoothing: Evidence from Indonesia', Economic Development and Cultural Change 60(3): 475-506.

Gertler, P. and J. Gruber (2002) 'Insuring Consumption Against Illness', American Economic Review 92(1): 5170.

Gruber, J., N. Hendren and R.M. Townsend (2014) 'The Great Equalizer: Health Care Access and Infant Mortality in Thailand', American Economic Journal: Applied Economics 6(1): 91-107.

Idler, E.L. and Y. Benyamini (1997) 'Self-Rated Health and Mortality: A Review of Twenty-Seven Community Studies', Journal of health and social behavior: 21-37.

Idler, E.L. and S.V. Kasl (1995) 'Self-Ratings of Health: Do they also Predict Change in Functional Ability?', The Journals of Gerontology Series B: Psychological Sciences and Social Sciences 50(6): S344-S353.

Imbens, G.W. and J.M. Wooldridge (2009) 'Recent Developments in the Econometrics of Program Evaluation', Journal of Economic Literature 47(1): 5-86.

International Labour Organization (2013) Social Protection Assessment Based National Dialogue: Towards a Nationally Defined Social Protection Floor in Thailand. Geneva: International Labour Office.

Islam, A. and P. Maitra (2012) 'Health Shocks and Consumption Smoothing in Rural Households: Does Microcredit have a Role to Play?', Journal of Development Economics 97(2): 232-243.

Jamison, D.T., L.H. Summers, G. Alleyne, K.J. Arrow, S. Berkley, A. Binagwaho et al. (2013) 'Global Health 2035: A World Converging within a Generation', The Lancet 382(9908): 1898-1955.

Jones, A. and O. O'Donnell (1995) 'Equivalence Scales and the Costs of Disability', Journal of Public Economics 56(2): 273-289.

Kowalski, A. (2015) 'What do Longitudinal Data on Millions of Hospital Visits Tell Us about the Value of Public Health Insurance as a Safety Net for the Young and Privately Insured?', No. NBER Working Paper No. 20887. Cambridge, MA: NBER.

Limwattananon, S., S. Neelsen, O. O'Donnell, P. Prakongsai, V. Tangcharoensathien, E. van Doorslaer et al. (2015) 'Universal Coverage with Supply-Side Reform: The Impact on Medical Expenditure Risk and Utilization in Thailand', Journal of Public Economics 121: 79-94.

Lindelow, M. and A. Wagstaff (2005) 'Health Shocks in China: Are the Poor and Uninsured Less Protected?', No. World Bank Policy Research Working Paper 3740. Washington DC: World Bank.

Lönnroth, K., P. Glaziou, D. Weil, K. Floyd, M. Uplekar and M. Raviglione (2014) 'Beyond UHC:

Monitoring Health and Social Protection Coverage in the Context of Tuberculosis Care and Prevention', PLOS medicine 11(9): e1001693. 
Ministry of Labour (Last updated 2012) 'Information about the Benefits of Disabled People'. Accessed 04/22 $2015<$ http://www.mol.go.th/en/content/page/6359>.

Mohanan, M. (2013) 'Causal Effects of Health Shocks on Consumption and Debt: Quasi-Experimental Evidence from Bus Accident Injuries', Review of Economics and Statistics 95(2): 673-681.

O'Donnell, O., E. Van Doorslaer and T. Van Ourti (2015) 'Health and Inequality', in A.B. Atkinson and F. Bourguignon (eds) Handbook of Income Distribution, Vol. 2B. pp. 1419-1533. Amsterdam: Elsevier.

Robins, J.M. and A. Rotnitzky (1995) 'Semiparametric Efficiency in Multivariate Regression Models with Missing Data', Joumal of the American Statistical Association 90(429): 122-129.

Social Security Administration (2013) Social Security Programs Throughout the World: Asia and the Pacific, 2012 Thailand. Washington, DC: Social Security Administration.

Sparrow, R., E. Van de Poel, G. Hadiwidjaja, A. Yumna, N. Warda and A. Suryahadi (2014) 'Coping with the Economic Consequences of Ill Health in Indonesia', Health Economics 23(6): 719-728.

Tanimura, T., E. Jaramillo, D. Weil, M. Raviglione and K. Lonnroth (2014) 'Financial Burden for Tuberculosis Patients in Low- and Middle-Income Countries: A Systematic Review', The European Respiratory Journal 43(6): 1763-1775.

Tantivess, S., Y. Teerawattananon and A. Mills (2009) 'Strengthening Cost-Effectiveness Analysis in Thailand through the Establishment of the Health Intervention and Technology Assessment Program.', Pharmacoeconomics 27(11): 931-945.

Townsend, R.M. (1994) 'Risk and Insurance in Village India', Econometrica 62(3): 539-591.

Wagstaff, A. (2007) 'The Economic Consequences of Health Shocks: Evidence from Vietnam', Journal of Health Economics 26(1): 82-100.

Wagstaff, A. and E. van Doorslaer (2003) 'Catastrophe and Impoverishment in Paying for Health Care: With Applications to Vietnam 1993-1998', Health Economics 12(11): 921-933.

World Health Organization (2010) 'The World Health Report - Health Systems Financing: The Path to Universal Coverage'. Geneva: World Health Organization.

World Health Organization (2001) 'Macroeconomics and Health: Investing in Health for Economic Development. Report of the Commission on Macroeconomics and Health, Geneva', World Health Organization.

Xu, K., D.B. Evans, K. Kawabata, R. Zeramdini, J. Klavus and C.J. Murray (2003) 'Household Catastrophic Health Expenditure: A Multicountry Analysis', The Lancet 362(9378): 111-117. 


\section{Appendix}

Table A1: Percentage of workforce covered by various health insurance schemes by employment sector, 2007

Employment sector

\begin{tabular}{|c|c|c|c|c|c|c|}
\hline \multirow[b]{2}{*}{ Employer } & \multirow[b]{2}{*}{$\begin{array}{c}\text { Self- } \\
\text { employed }\end{array}$} & \multirow[b]{2}{*}{$\begin{array}{l}\text { Family } \\
\text { worker }\end{array}$} & \multicolumn{3}{|c|}{ Private enterprise employee } & \\
\hline & & & $\begin{array}{c}\text { Micro } \\
(<10 \\
\text { employees) }\end{array}$ & $\begin{array}{c}\text { Small } \\
(<50 \\
\text { employees) }\end{array}$ & $\begin{array}{l}\text { Medium \& } \\
\text { large (>50 } \\
\text { employees) }\end{array}$ & $\begin{array}{c}\text { sector } \\
\text { employee }\end{array}$ \\
\hline
\end{tabular}

All

employees) employees) employees)

Insurance scheme

\begin{tabular}{rcccccccc} 
Uninsured & 5.88 & 4.80 & 3.57 & 4.65 & 2.74 & 0.93 & 0.87 & 3.45 \\
Universal Coverage & 74.51 & 85.41 & 89.48 & 83.64 & 58.55 & 13.89 & 12.62 & 65.70 \\
Social Security & 5.39 & 1.66 & 1.90 & 9.09 & 35.41 & 80.50 & 17.49 & 18.59 \\
Civil Servants Medical Benefit & 10.05 & 7.30 & 4.24 & 2.04 & 2.10 & 3.24 & 68.41 & 11.24 \\
Other & 4.17 & 0.83 & 0.81 & 0.58 & 1.19 & 1.43 & 0.61 & 1.01 \\
\hline Total & 100 & 100 & 100 & 100 & 100 & 100 & 100 & 100 \\
\hline
\end{tabular}

Notes: Data from 2007 Thai Socioeconomic Survey panel household members. Individuals who are not public servants are covered by the Civil Servants Medical Benefit Scheme if they are dependents of public servants. The Social Security Scheme is intended to cover formal, private sector employees.

Table A2: Baseline (2005) means of covariates included in household level analyses by treatment status

\begin{tabular}{|c|c|c|c|}
\hline & $\begin{array}{l}\text { Onset of health problem } \\
\text { (treatment) } \\
\text { (1) }\end{array}$ & $\begin{array}{l}\text { No onset of health } \\
\text { problem (control) } \\
\text { (2) }\end{array}$ & $\begin{array}{l}(1)=(2) \\
\text { p-value }\end{array}$ \\
\hline Mean age & 36.40 & 33.85 & 0.000 \\
\hline Mean share of males & 0.487 & 0.492 & 0.674 \\
\hline$=1$ if urban & 0.338 & 0.343 & 0.853 \\
\hline \# of household members & 3.875 & 4.115 & 0.016 \\
\hline \# of healthy informal workers & 1.651 & 1.501 & 0.000 \\
\hline \# of healthy other workers & 0.270 & 0.304 & 0.355 \\
\hline \# of healthy non-workers & 0.381 & 0.380 & 0.960 \\
\hline \multicolumn{4}{|l|}{ Education, share of members $>14$ with } \\
\hline$\leq$ primary & 0.682 & 0.642 & 0.042 \\
\hline secondary & 0.201 & 0.243 & 0.010 \\
\hline$>$ secondary & 0.117 & 0.115 & 0.881 \\
\hline \multicolumn{4}{|l|}{ Occupation, share of members $>14$ who are } \\
\hline non-working & 0.179 & 0.204 & 0.055 \\
\hline in agriculture & 0.311 & 0.303 & 0.734 \\
\hline blue collar & 0.128 & 0.112 & 0.243 \\
\hline in retail/trade & 0.235 & 0.232 & 0.887 \\
\hline white collar & 0.147 & 0.149 & 0.901 \\
\hline \multicolumn{4}{|c|}{ Employment sector, share of members $>14$ who are } \\
\hline employers & 0.062 & 0.070 & 0.431 \\
\hline self-employed & 0.317 & 0.293 & 0.118 \\
\hline family workers & 0.177 & 0.185 & 0.542 \\
\hline micro-firm employees & 0.167 & 0.144 & 0.130 \\
\hline small/mid-size firm employees & 0.028 & 0.029 & 0.847 \\
\hline large firm employees & 0.035 & 0.044 & 0.231 \\
\hline public sector employees & 0.035 & 0.032 & 0.643 \\
\hline Observations & 367 & 1,665 & \\
\hline
\end{tabular}


Table A3: Baseline (2005) means of outcomes and covariates for treatment and control groups, by health problem onset severity

Individual

Household

\begin{tabular}{|c|c|c|c|c|c|c|c|c|c|c|c|c|c|c|c|}
\hline & $\begin{array}{c}\text { drop to } \\
\text { poor health }\end{array}$ & $(1)=(4)$ & $\begin{array}{c}\text { drop to fair } \\
\text { health }\end{array}$ & $\begin{array}{l}\text { th proble } \\
(2)=(4)\end{array}$ & $\begin{array}{l}\mathrm{m}+ \\
\text { remaining } \\
\text { in very } \\
\text { good/good } \\
\text { health }\end{array}$ & $(3)=(4)$ & $\begin{array}{l}\text { No onset } \\
\text { of health } \\
\text { problem } \\
\text { (control) }\end{array}$ & & $\begin{array}{c}\text { drop to } \\
\text { poor health }\end{array}$ & $(5)=(8)$ & $\begin{array}{c}\text { drop to } \\
\text { fair health }\end{array}$ & $(6)=(8)$ & $\begin{array}{l}\text { lem }+ \\
\text { remaining } \\
\text { in very } \\
\text { good/good } \\
\text { health }\end{array}$ & $(7)=(8)$ & $\begin{array}{l}\text { No onset } \\
\text { of health } \\
\text { problem } \\
\text { (control) }\end{array}$ \\
\hline & (1) & $\mathrm{p}$-value & (2) & $\mathrm{p}$-value & (3) & $\mathrm{p}$-value & (4) & & (5) & $\mathrm{p}$-value & (6) & $\mathrm{p}$-value & (7) & $\mathrm{p}$-value & (8) \\
\hline Hours worked (week) & 49.94 & 0.708 & 47.19 & 0.160 & 47.08 & 0.174 & 48.86 & Hours worked & 28.87 & 0.799 & 31.63 & 0.078 & 29.46 & 0.878 & 29.65 \\
\hline Age (years) & 46.15 & 0.001 & 47.47 & 0.000 & 45.80 & 0.000 & 39.14 & Labor income (Baht) & 7,227 & 0.964 & 4,134 & 0.429 & 7,104 & 0.934 & 6,793 \\
\hline 1 if male & 0.576 & 0.851 & 0.450 & 0.002 & 0.509 & 0.196 & 0.559 & OOP amount (Baht) & 23.29 & 0.252 & 58.62 & 0.615 & 67.65 & 0.230 & 52.77 \\
\hline 1 if urban & 0.394 & 0.404 & 0.306 & 0.568 & 0.327 & 0.955 & 0.325 & OOP budget share & 0.008 & 0.371 & 0.019 & 0.550 & 0.019 & 0.605 & 0.017 \\
\hline Education & & 0.493 & & 0.000 & & 0.121 & & 1 if OOP budget share $>.1$ & 0.000 & 0.531 & 0.043 & 0.488 & 0.034 & 0.992 & 0.034 \\
\hline 1 if $\leq$ primary & 0.758 & & 0.794 & & 0.696 & & 0.661 & 1 if any non-labor income & 0.435 & 0.973 & 0.500 & 0.074 & 0.426 & 0.896 & 0.431 \\
\hline 1 if secondary & 0.182 & & 0.144 & & 0.175 & & 0.238 & Non-labor income & 384.7 & 0.669 & 650.1 & 0.862 & 648.0 & 0.883 & 615.3 \\
\hline 1 if $>$ secondary & 0.061 & & 0.062 & & 0.129 & & 0.101 & Total income & 7,612 & 0.983 & 4,784 & 0.440 & 7,752 & 0.928 & 7,408 \\
\hline Occupation & & 0.666 & & 0.006 & & 0.815 & & 1 if any savings & 0.478 & 0.109 & 0.630 & 0.793 & 0.689 & 0.233 & 0.640 \\
\hline 1 if agriculture & 0.424 & & 0.450 & & 0.427 & & 0.409 & Savings (Baht) & 402.6 & 0.406 & 644.4 & 0.169 & 1,103 & 0.706 & 994.8 \\
\hline 1 if blue collar & 0.061 & & 0.191 & & 0.117 & & 0.133 & 1 if any borrowing & 0.348 & 0.245 & 0.484 & 0.718 & 0.541 & 0.098 & 0.470 \\
\hline 1 if retail/trade & 0.394 & & 0.301 & & 0.357 & & 0.341 & Borrowing (Baht) & 1,098 & 0.962 & 756.9 & 0.222 & 2,225 & 0.005 & 1,140 \\
\hline 1 if white collar & 0.121 & & 0.057 & & 0.099 & & 0.117 & Non-medical expenditure & 2,871 & 0.665 & 2,740 & 0.100 & 3,671 & 0.176 & 3,220 \\
\hline Employment sector & & 0.680 & & 0.798 & & 0.407 & 0.736 & & & & & & & & \\
\hline 1 if employer & 0.061 & & 0.077 & & 0.105 & & 0.092 & & & & & & & & \\
\hline 1 if self-employed & 0.333 & & 0.435 & & 0.456 & & 0.407 & & & & & & & & \\
\hline 1 if family worker & 0.333 & & 0.273 & & 0.222 & & 0.274 & & & & & & & & \\
\hline 1 if micro firm & 0.273 & & 0.215 & & 0.216 & & 0.227 & & & & & & & & \\
\hline Observations & 33 & & 209 & & 171 & & 2,692 & & 23 & & 184 & & 148 & & 1,665 \\
\hline
\end{tabular}

Notes: Samples as defined in notes to Table 2. Cells show mean values in the first (2005) wave. p-values are for test of equality of means/proportions across groups and are obtained from chi2-test for categorical variables (education, occupation and employment sector). At household level, hours worked is the total hours worked per household member older than 14 years. All monetary amounts are per capita per month. OOP amount is household out-of-pocket spending on medical care and medicines. OOP budget share is OOP spending as proportion of household total expenditure. Borrowing is the amount borrowed in the last month. 
Table A4: Robustness of estimated effects of the onset of a health problem on labor supply and income

\begin{tabular}{|c|c|c|c|c|}
\hline & \multicolumn{2}{|c|}{ Individual } & \multicolumn{2}{|c|}{ Household } \\
\hline & Employment & $\begin{array}{c}\text { Log working } \\
\text { hours }\end{array}$ & $\begin{array}{c}\text { Log working } \\
\text { hours per } \\
\text { member }>14\end{array}$ & $\begin{array}{c}\text { Log labor } \\
\text { income per } \\
\text { capita }\end{array}$ \\
\hline \multicolumn{5}{|l|}{ Onset of a health problem } \\
\hline Baseline estimate (lagged dependent vbl. model) & $\begin{array}{c}-0.037 * * * \\
(0.012)\end{array}$ & $\begin{array}{c}-0.139 * * * \\
(0.049)\end{array}$ & $\begin{array}{c}-0.054 * \\
(0.032)\end{array}$ & $\begin{array}{l}-0.059 \\
(0.050)\end{array}$ \\
\hline Baseline with inverse probability weights & $\begin{array}{c}-0.028^{* * *} \\
(0.009)\end{array}$ & $\begin{array}{c}-0.110^{* * *} \\
(0.035)\end{array}$ & $\begin{array}{l}-0.049 \\
(0.032)\end{array}$ & $\begin{array}{l}-0.065 \\
(0.050)\end{array}$ \\
\hline Baseline with covariates as in first difference model & $\begin{array}{c}-0.029 * * * \\
(0.009)\end{array}$ & $\begin{array}{l}-0.119 * * * \\
(0.034)\end{array}$ & $\begin{array}{l}-0.031 \\
(0.032)\end{array}$ & $\begin{array}{l}-0.052 \\
(0.050)\end{array}$ \\
\hline \multicolumn{5}{|l|}{ First difference model } \\
\hline Onset of a health problem & $\begin{array}{c}-0.037 * * * \\
(0.009)\end{array}$ & $\begin{array}{c}-0.158^{* * *} \\
(0.035)\end{array}$ & $\begin{array}{c}-0.084 * * \\
(0.034)\end{array}$ & $\begin{array}{l}-0.092^{*} \\
(0.055)\end{array}$ \\
\hline $\begin{array}{l}\text { Onset of a health problem }+ \\
\text { drop to poor health }\end{array}$ & $\begin{array}{c}-0.125^{* * *} \\
(0.044)\end{array}$ & $\begin{array}{c}-0.442^{* *} \\
(0.172)\end{array}$ & $\begin{array}{l}-0.166 \\
(0.121)\end{array}$ & $\begin{array}{l}-0.081 \\
(0.203)\end{array}$ \\
\hline drop to fair health & $\begin{array}{c}-0.027 * * * \\
(0.010)\end{array}$ & $\begin{array}{c}-0.124 * * * \\
(0.039)\end{array}$ & $\begin{array}{l}-0.087^{*} \\
(0.051)\end{array}$ & $\begin{array}{l}-0.029 \\
(0.076)\end{array}$ \\
\hline remain in very good/good health & $\begin{array}{c}-0.033^{* * *} \\
(0.012)\end{array}$ & $\begin{array}{l}-0.105^{* *} \\
(0.052)\end{array}$ & $\begin{array}{l}-0.062 \\
(0.044)\end{array}$ & $\begin{array}{c}-0.161 * * \\
(0.077)\end{array}$ \\
\hline$N$ & 6,469 & 6,469 & 4,175 & 4,175 \\
\hline
\end{tabular}

Notes: Table to be compared with the baseline estimates in Table 5 of main text. First row reproduces the baseline estimates of the effects of any health problem obtained from model (1). Second row is from same model with application of inverse probability weights. Third row is from same model (without IPW) with the covariates restricted to those used in the first difference model estimates presented in second panel i.e. without employment-related covariates. First difference estimates given for effects of any health problem and by degree of change in self-assessed health. All regressions models estimated by OLS. Samples as defined in notes to Table 2. Standard errors clustered at individual/household level in parentheses. $* * *, * *, *$ indicate statistical significance at 1,5 and $10 \%$ levels.

Table A5: Robustness of estimated effects of the onset of a health problem on out-of-pocket medical expenditure

\begin{tabular}{|c|c|c|c|}
\hline & Log OOP per capita & $\begin{array}{l}\text { OOP/total } \\
\text { expenditure }\end{array}$ & $\begin{array}{c}\text { If OOP / total } \\
\text { expenditure }>0.1\end{array}$ \\
\hline \multicolumn{4}{|l|}{ Onset of a health problem } \\
\hline Baseline estimate (lagged dependent vbl. model) & $\begin{array}{c}0.537 * * * \\
(0.080)\end{array}$ & $\begin{array}{c}0.006 * * * \\
(0.002)\end{array}$ & $\begin{array}{c}0.021 * * \\
(0.008)\end{array}$ \\
\hline Baseline with inverse probability weights & $\begin{array}{l}0.521 * * * \\
(0.078)\end{array}$ & $\begin{array}{l}0.006^{* * *} \\
(0.002)\end{array}$ & $\begin{array}{l}0.022^{* * *} \\
(0.008)\end{array}$ \\
\hline Baseline with covariates as in first difference model & $\begin{array}{c}0.507 * * * \\
(0.079)\end{array}$ & $\begin{array}{c}0.005^{* * *} \\
(0.002)\end{array}$ & $\begin{array}{l}0.018^{* *} \\
(0.008)\end{array}$ \\
\hline \multicolumn{4}{|l|}{ First-difference model } \\
\hline Onset of a health problem & $\begin{array}{c}0.402^{* * *} \\
(0.099)\end{array}$ & $\begin{array}{l}0.005^{* *} \\
(0.002)\end{array}$ & $\begin{array}{l}0.021 * * \\
(0.010)\end{array}$ \\
\hline $\begin{array}{l}\text { Onset of a health problem }+ \\
\text { drop to poor health }\end{array}$ & $\begin{array}{l}0.961^{* * *} \\
(0.293)\end{array}$ & $\begin{array}{c}0.023 * * * \\
(0.007)\end{array}$ & $\begin{array}{c}0.112^{* * *} \\
(0.038)\end{array}$ \\
\hline drop to fair health & $\begin{array}{c}0.388^{* * *} \\
(0.133)\end{array}$ & $\begin{array}{c}0.005 \\
(0.003)\end{array}$ & $\begin{array}{c}0.032 * * \\
(0.016)\end{array}$ \\
\hline remain in very good/good health & $\begin{array}{c}0.283^{*} \\
(0.145)\end{array}$ & $\begin{array}{c}0.001 \\
(0.003)\end{array}$ & $\begin{array}{l}-0.006 \\
(0.013)\end{array}$ \\
\hline$N$ & 4,175 & 4,175 & 4,175 \\
\hline
\end{tabular}

Notes: Table to be compared with the baseline estimates in Table 6. Notes to Table A4 apply but standard errors clustered at household level in parentheses. 
Table A6: Robustness of estimated effects of the onset of a health problem on monthly savings and borrowing

\begin{tabular}{|c|c|c|c|c|c|c|}
\hline & \multicolumn{2}{|c|}{ Monthly savings } & \multicolumn{2}{|c|}{ Borrowing } & \multicolumn{2}{|c|}{ Non-labor income } \\
\hline & $\begin{array}{l}=1 \text { if } \\
\text { any }\end{array}$ & $\begin{array}{c}\text { Log per } \\
\text { capita } \\
\text { amount }\end{array}$ & $\begin{array}{l}=1 \text { if } \\
\text { any }\end{array}$ & $\begin{array}{l}\text { Log per } \\
\text { capita } \\
\text { amount }\end{array}$ & $\begin{array}{l}=1 \text { if } \\
\text { any }\end{array}$ & $\begin{array}{c}\text { Log per } \\
\text { capita } \\
\text { amount }\end{array}$ \\
\hline Onset of a health problem & & & & & & \\
\hline Baseline estimate (lagged dependent vbl. model) & $\begin{array}{l}-0.011 \\
(0.017)\end{array}$ & $\begin{array}{l}-0.115 \\
(0.103)\end{array}$ & $\begin{array}{c}0.056^{* * *} \\
(0.018)\end{array}$ & $\begin{array}{c}0.288^{* * *} \\
(0.100)\end{array}$ & $\begin{array}{l}0.042^{* *} \\
(0.018)\end{array}$ & $\begin{array}{l}0.271 * * \\
(0.115)\end{array}$ \\
\hline Baseline with inverse probability weights & $\begin{array}{l}-0.007 \\
(0.018)\end{array}$ & $\begin{array}{l}-0.100 \\
(0.108)\end{array}$ & $\begin{array}{c}0.054 * * * \\
(0.018)\end{array}$ & $\begin{array}{c}0.282^{* * *} \\
(0.095)\end{array}$ & $\begin{array}{c}0.042 * * \\
(0.019)\end{array}$ & $\begin{array}{c}0.280 * * \\
(0.117)\end{array}$ \\
\hline Baseline with covariates as in first difference model & $\begin{array}{l}-0.007 \\
(0.017)\end{array}$ & $\begin{array}{l}-0.097 \\
(0.103)\end{array}$ & $\begin{array}{l}0.059 * * * \\
(0.018)\end{array}$ & $\begin{array}{c}0.301 * * * \\
(0.100)\end{array}$ & $\begin{array}{c}0.028 \\
(0.018)\end{array}$ & $\begin{array}{c}0.184 \\
(0.115)\end{array}$ \\
\hline First difference model & & & & & & \\
\hline Onset of a health problem & $\begin{array}{l}-0.002 \\
(0.021)\end{array}$ & $\begin{array}{l}-0.105 \\
(0.126)\end{array}$ & $\begin{array}{l}0.041 * \\
(0.022)\end{array}$ & $\begin{array}{c}0.184 \\
(0.124)\end{array}$ & $\begin{array}{c}0.029 \\
(0.023)\end{array}$ & $\begin{array}{l}0.233^{*} \\
(0.141)\end{array}$ \\
\hline $\begin{array}{l}\text { Onset of a health problem }+ \\
\text { drop to poor health }\end{array}$ & $\begin{array}{l}-0.023 \\
(0.044)\end{array}$ & $\begin{array}{c}-0.393 \\
(0.058)\end{array}$ & $\begin{array}{c}0.173 * * * \\
(0.352)\end{array}$ & $\begin{array}{c}0.623^{*} \\
(0.065)\end{array}$ & $\begin{array}{l}-0.012 \\
(0.074)\end{array}$ & $\begin{array}{l}-0.053 \\
(0.428)\end{array}$ \\
\hline drop to fair health & $\begin{array}{c}0.012 \\
(0.010)\end{array}$ & $\begin{array}{l}-0.012 \\
(0.030)\end{array}$ & $\begin{array}{c}0.014 \\
(0.170)\end{array}$ & $\begin{array}{c}0.098 \\
(0.030)\end{array}$ & $\begin{array}{c}0.003 \\
(0.031)\end{array}$ & $\begin{array}{c}0.073 \\
(0.189)\end{array}$ \\
\hline remain in very good/good health & $\begin{array}{l}-0.002 \\
(0.030)\end{array}$ & $\begin{array}{l}-0.066 \\
(0.179)\end{array}$ & $\begin{array}{c}0.048 \\
(0.032)\end{array}$ & $\begin{array}{c}0.222 \\
(0.186)\end{array}$ & $\begin{array}{l}0.058^{*} \\
(0.033)\end{array}$ & $\begin{array}{c}0.462^{* *} \\
(0.201)\end{array}$ \\
\hline$N$ & 4,175 & 4,175 & 4,175 & 4,175 & 4,175 & 4,175 \\
\hline
\end{tabular}

Notes: Table to be compared with the baseline estimates presented in Table 7 of main text. Notes to Table A4 apply but standard errors clustered at household level in parentheses.

Table A7: Robustness of estimated effects of the onset of a health problem on household non-labor and total income, and non-health expenditure

\begin{tabular}{|c|c|c|}
\hline & $\begin{array}{l}\text { Log per capita total } \\
\text { income }\end{array}$ & $\begin{array}{l}\text { Log per capita non- } \\
\text { health expenditure }\end{array}$ \\
\hline \multicolumn{3}{|l|}{ Onset of a health problem } \\
\hline Baseline estimate (lagged dependent vbl. model) & $\begin{array}{c}0.009 \\
(0.028)\end{array}$ & $\begin{array}{c}0.020 \\
(0.020)\end{array}$ \\
\hline Baseline with inverse probability weights & $\begin{array}{c}0.007 \\
(0.028)\end{array}$ & $\begin{array}{c}0.020 \\
(0.021)\end{array}$ \\
\hline Baseline with covariates as in first difference model & $\begin{array}{c}0.009 \\
(0.028)\end{array}$ & $\begin{array}{c}0.023 \\
(0.020)\end{array}$ \\
\hline \multicolumn{3}{|l|}{ First difference model } \\
\hline Onset of a health problem & $\begin{array}{c}0.000 \\
(0.033)\end{array}$ & $\begin{array}{c}0.022 \\
(0.024)\end{array}$ \\
\hline $\begin{array}{l}\text { Onset of a health problem }+ \\
\text { drop to poor health }\end{array}$ & $\begin{array}{l}-0.078 \\
(0.083)\end{array}$ & $\begin{array}{l}-0.025 \\
(0.059)\end{array}$ \\
\hline drop to fair health & $\begin{array}{l}-0.003 \\
(0.039)\end{array}$ & $\begin{array}{l}-0.000 \\
(0.027)\end{array}$ \\
\hline remain in very good/good health & $\begin{array}{c}0.048 \\
(0.037)\end{array}$ & $\begin{array}{l}0.054 * * \\
(0.027)\end{array}$ \\
\hline$N$ & 4,175 & 4,175 \\
\hline
\end{tabular}

